\section{Indicators of Maturity and Storage Quality of 'Lapins' Sweet Cherry}

\author{
S.R. Drake ${ }^{1}$ and D.C. Elfving ${ }^{2}$
}

Additional index words. Prunus avium, fruit maturity

Summary. Three commercial 'Lapins' sweet cherry (Prunus avium) orchards were used for this study during three crop seasons. Orchards were selected based on the historical average date of commercial harvest. The difference in commercial harvest date among the three orchards was 5 to 7 days. Three harvests were carried out in each orchard each year: 1) beginning 4 to 5 days before commercial harvest, 2) at commercial harvest, and 3) 4 to 5 days after commercial harvest. Fruit quality was determined after $0,7,14$, and 21 days of storage. Harvesting fruit up to $\mathbf{5}$ days later than normal commercial harvest resulted in increases in fruit weight and soluble solids content along with no loss of firmness or change in acidity. Pedicel color did not change as harvest was delayed. Changes in visual ratings of both fruit and pedicel appearance with delayed harvest were detectable in only 1 of 3 years. Neither pitting nor bruising was influenced by harvest date. The amount of pitting or bruising present was related more to the year of harvest than to harvest date. Delaying harvest a short time beyond the normal commercial harvest date could enhance consumer appeal and increase fruit value. Storage time after harvest resulted in reduced fruit and pedicel appearance, but only beyond 14 days of storage.

$\mathrm{V}$ ariability in the maturity of sweet cherries is related to several factors, including crop load (Drake and Fellman, 1987; Proebsting and Mills, 1981), fruit to

${ }^{1}$ Research horticulturist, USDA-ARS-TFRL, $1104 \mathrm{~N}$. Western Ave., Wenatchee, WA. 98801

${ }^{2}$ Horticulturist and professor, Washington State University, Tree Fruit Research and Extension Center, 1100 N. Western Ave., Wenatchee, WA 98801. leaf ratio (Facteau and Rowe, 1979), location on the tree (Ingalsbe et al., 1965 ) and exposure to light (Patten and Proebsting, 1986). Harvest decisions represent a compromise between delaying harvest to attain improved flavor and color versus picking early, before the cherries soften excessively. Soluble solids content (SSC), titratable acidity (TA), SSC/TA ratio, skin color, and firmness have all been used as indices for cherry fruit maturity (Crisosto et al., 1997; Drake et al., 1982; Guyer et al., 1993; Hansche et al., 1988; Harman and Bullis, 1929), but skin color has long been accepted as the best indicator for the appropriate harvest maturity of sweet cherries (Drake and Fellman, 1987; Ingalsbe et al., 1965). Crisosto et al. (2001) determined that cherry flavor intensity was highly correlated to color, SSC, and SSC/TA ratio at harvest.

'Lapins' is a dark-colored sweet cherry cultivar planted extensively in the state of Washington that matures 7 to $10 \mathrm{~d}$ later than 'Bing'. 'Lapins' is of commercial interest because of its large size and resistance to rain cracking, but problems associated with maturity (pitting, stem condition, size, flavor) of this cultivar also have been reported by packers (T. Facteau and E.M. Kupferman, personal communications). To meet market and labor demands, 'Lapins' cherries are often picked before they have attained full flavor and proper maturity. Quality problems associated with maturity can be readily visible to the consumer, reducing market appeal of this fruit. This study was conducted to evaluate physical measurements of fruit quality as a maturity index for estimating proper harvest time and subsequent storage quality of 'Lapins' cherries.

\section{Materials and methods}

Three commercial 'Lapins' cherry orchards were used for this study during three crop seasons (1999, 2000, and 2001). The orchards were selected based on the historical average date of commercial harvest. The difference in commercial harvest date among the three orchards was 5 to $7 \mathrm{~d}$. Three to four trees were selected at random in each orchard based on uniform crop load. Three harvests were conducted in each orchard each year: 1) beginning 4 to $5 \mathrm{~d}$ before commercial harvest, 2) at commercial harvest, and 3 ) 4 to $5 \mathrm{~d}$ after commercial harvest. On each harvest date a $1-k g(2.2-\mathrm{lb})$ sample of fruit was collected randomly from around the perimeter of each tree 1 to $3 \mathrm{~m}$ (3.3 to $9.8 \mathrm{ft})$ above the ground. After each harvest, 50 fruit from each tree were immediately evaluated for weight, fruit, and pedicel color, firmness, SSC, titratable acidity (TA), number of fruit in each sample exhibiting pitting and bruising, and subjective acceptance evaluations of fruit and pedicel appearance. The remaining fruit from each orchard and tree were placed in fiberboard cartons, $20 \times 14.5 \times 9 \mathrm{~cm}$ $(7.9 \times 5.7 \times 3.5$ inches $)$ with a polyethylene liner. These containers were then placed in storage at $1{ }^{\circ} \mathrm{C}\left(33.8^{\circ} \mathrm{F}\right)$. After 7, 14, and $21 \mathrm{~d}$ of storage, a similar-sized fruit subsample was removed from each carton and evaluated as described above.

Fruit and pedicel color were evaluated with a Minolta CR300 (Osaka, Japan) using the Hunter $L^{*}, a^{*}, b^{*}$ system and calculated hue values (Hunter and Harold, 1987). Firmness was determined using the Universal TA-XT2 texture analyzer (Scarsdale, N.Y.) equipped with a $3-\mathrm{mm}$ probe that penetrated the fruit flesh a distance of $5 \mathrm{~mm}$ (after contact at a velocity of $10 \mathrm{~mm} / \mathrm{s}$ ). Values were converted to Newtons (N). Fruit SSC was determined by an Abbé-type refractometer with a sucrose scale calibrated at $20{ }^{\circ} \mathrm{C}\left(68.0{ }^{\circ} \mathrm{F}\right)$. TA was determined by titration to $\mathrm{pH} 8.2$ with $0.1 \mathrm{~N}$ sodium hydroxide, expressing the values as the equivalent percentage of malic acid. The percentages of pitted and bruised fruit were calculated from the number of fruit in a sample showing pitting and/or bruising. Subjective ratings of fruit and pedicel appearance were determined individually on a scale of 1 to 3 ( $1=$ excellent, 2 = acceptable, 3 = unacceptable) using two laboratory personnel familiar with cherry grades.

All data were subjected to analysis of variance or regression using the General Linear Models (GLM) procedure of the Statistical Analysis System program package (SAS Inst., Cary, N.C.). Means were separated using the Waller-Duncan Bayesian $\mathrm{k}$ ratio test when significant $\mathrm{F}$ values $(P \leq$ 0.05 ) were determined. Analyses of regression on storage time in factorial combination with harvest date assessed the presence of significant linear and curvilinear effects of storage time and the homogeneity of intercepts, slopes, 
and second-order curvatures among harvest dates (Snedecor and Cochran, 1980). Where a difference between slopes, intercepts, or curvatures indicated separate regression relations among harvest dates, each regression was individually tested for significant linear and quadratic effects. In the absence of such differences, linear and quadratic effects were tested for the overall regression on storage time.

\section{Results and discussion}

Time of harvest influenced fruit size of 'Lapins' sweet cherries (Table 1). Regardless of the year, fruit size increased with later harvest, particularly between the early and commercial harvest dates. Fruit weight increased from $6.5 \%$ to $13.6 \%$ depending upon the year, but there was little influence on fruit weight after the date of commercial harvest. Time in storage had no influence on fruit weight. After $21 \mathrm{~d}$ of storage, fruit weight was similar to that immediately after harvest. Fruit firmness was not related to either harvest date or storage time in 1999 or 2001 . In 2000, late-harvested fruit were less firm than fruit from either the early harvest or the commercial harvest date. Fruit firmness increased with longer storage time (from 0 to $2 \mathrm{ld}$ ). This increased firmness may have been related to moisture loss, although no significant weight loss was detected over the storage period in any year.

As would be expected, a delay in harvest date resulted in increased SSC, but only in 2 of the 3 years of this study. In the third year there was no change in the SSC regardless of the time of harvest, even though there was a trend toward increased SSC as harvest was delayed. SSC was not influenced by time in storage, which would contradict the theory that moisture loss may be related to firmness. If moisture loss had accompanied time in storage, the SSC value of the cherries should have increased.

TA was influenced by harvest date only during 1 year (2000). In 2000, TA values increased as harvest was delayed. TA was reduced as storage time increased, regardless of the year in question. As storage time increased from 0 to $21 \mathrm{~d}$, TA decreased $14 \%$ to $23 \%$. This loss of acidity over storage times has been observed in other studies (Drake and Fellman, 1987; Harman and Bullis, 1929; Proebsting and Mills,

Table 1. Quality attributes of 'Lapins' sweet cherries as influenced by harvest date and storage time over three crop seasons.

\begin{tabular}{|c|c|c|c|c|c|c|c|c|c|c|c|c|}
\hline \multirow[b]{2}{*}{ Factor } & \multicolumn{3}{|c|}{ Wt/cherry $(g)^{z}$} & \multicolumn{3}{|c|}{ Firmness $(\mathbf{N})^{z}$} & \multicolumn{3}{|c|}{$\begin{array}{c}\text { Soluble solids } \\
\text { content }(\%)\end{array}$} & \multicolumn{3}{|c|}{$\begin{array}{l}\text { Titratable acidity } \\
\text { (\% malic) }\end{array}$} \\
\hline & 1999 & 2000 & 2001 & 1999 & 2000 & 2001 & 1999 & 2000 & 2001 & 1999 & 2000 & 2001 \\
\hline \multicolumn{13}{|l|}{ Harvest $^{y}$} \\
\hline Early & $10.6 b^{x}$ & $12.2 \mathrm{~b}$ & $8.3 \mathrm{~b}$ & $6.7 \mathrm{a}$ & $6.0 \mathrm{a}$ & $5.1 \mathrm{a}$ & $17.7 \mathrm{c}$ & $17.1 \mathrm{c}$ & $17.0 \mathrm{a}$ & $0.50 \mathrm{a}$ & $0.51 \mathrm{c}$ & $0.43 \mathrm{a}$ \\
\hline Commercial & $10.9 \mathrm{ab}$ & $12.9 \mathrm{a}$ & $9.4 \mathrm{a}$ & $6.3 \mathrm{a}$ & $5.9 \mathrm{a}$ & $4.7 \mathrm{a}$ & $18.6 \mathrm{~b}$ & $18.0 \mathrm{~b}$ & $17.4 \mathrm{a}$ & $0.5 \mathrm{l} \mathrm{a}$ & $0.55 \mathrm{~b}$ & $0.43 \mathrm{a}$ \\
\hline Late & $11.5 \mathrm{a}$ & $13.0 \mathrm{a}$ & $9.5 \mathrm{a}$ & $6.3 \mathrm{a}$ & $5.5 \mathrm{~b}$ & $4.3 \mathrm{a}$ & $19.7 \mathrm{a}$ & $18.6 \mathrm{a}$ & $17.9 \mathrm{a}$ & $0.53 \mathrm{a}$ & $0.58 \mathrm{a}$ & $0.43 \mathrm{a}$ \\
\hline \multicolumn{13}{|l|}{ Storage $(\mathrm{d})$} \\
\hline 0 & 11.1 & 13.0 & 9.3 & 6.4 & 5.4 & 4.6 & 18.7 & 17.9 & 17.7 & 0.59 & 0.60 & 0.47 \\
\hline 7 & --- & 12.6 & 9.4 & --- & 5.6 & 4.6 & --- & 17.8 & 17.3 & --- & 0.57 & 0.42 \\
\hline 14 & 11.0 & 12.7 & 8.7 & 6.4 & 5.9 & 4.8 & 18.7 & 18.0 & 17.3 & 0.49 & 0.52 & 0.40 \\
\hline 21 & 10.9 & 12.6 & --- & 6.5 & 6.3 & --- & 18.5 & 18.1 & --- & 0.45 & 0.51 & --- \\
\hline $\mathrm{L}$ & NS & NS & NS & NS & NS & NS & NS & NS & NS & $* * * *$ & $* * *$ & $* * *$ \\
\hline $\mathrm{C}$ & NS & NS & NS & NS & NS & NS & NS & NS & NS & NS & NS & NS \\
\hline
\end{tabular}

${ }^{\mathrm{z}} 28.35 \mathrm{~g}=1.0 \mathrm{oz}, 4.45 \mathrm{~N}=1.0 \mathrm{lb}$ of force.

yHarvest dates: early $=4$ to $5 \mathrm{~d}$ before commercial harvest date; commercial $=$ commercial harvest date; late $=4$ to $5 \mathrm{~d}$ after commercial harvest date

${ }^{\mathrm{x}}$ Means in a column within harvest not followed by a common letter are significantly different $(P \leq 0.05)$.

$\mathrm{ns}^{* * * * * * * * * * * *}$ Nonsignificant or significant at $P \leq 0.05,0.01,0.001,0.0001$, respectively; $\mathrm{L}=$ linear effect, $\mathrm{C}=\mathrm{curvilinear}$ effect.

Table 2. Fruit and pedicel color of 'Lapins' sweet cherries as influenced by harvest date and storage.

\begin{tabular}{|c|c|c|c|c|c|c|c|c|c|c|c|}
\hline \multirow[b]{3}{*}{ Factor } & \multicolumn{6}{|c|}{ Fruit } & \multicolumn{5}{|c|}{ Pedicel } \\
\hline & \multicolumn{3}{|c|}{$\mathbf{L}^{*}$} & \multicolumn{3}{|c|}{ Hue } & \multicolumn{2}{|c|}{$\mathbf{L}^{*}$} & \multicolumn{3}{|c|}{ Hue } \\
\hline & 1999 & 2000 & 2001 & 1999 & 2000 & 2001 & 1999 & 2000 & 2001 & 2000 & 2001 \\
\hline \multicolumn{12}{|l|}{ Harvest $^{\mathrm{y}}$} \\
\hline Early & $29.3 \mathrm{a}^{\mathrm{y}}$ & $30.4 \mathrm{a}$ & $24.3 \mathrm{a}$ & $18.4 \mathrm{a}$ & $9.9 \mathrm{~b}$ & $11.0 \mathrm{a}$ & $32.8 \mathrm{a}$ & $33.2 \mathrm{a}$ & $36.7 \mathrm{a}$ & $108 \mathrm{a}$ & $116 a$ \\
\hline Commercial & $26.7 \mathrm{a}$ & $27.1 \mathrm{c}$ & $23.6 \mathrm{a}$ & $14.1 \mathrm{~b}$ & $11.1 \mathrm{~b}$ & $9.5 \mathrm{~b}$ & $29.1 \mathrm{~b}$ & $32.1 \mathrm{~b}$ & $35.2 \mathrm{a}$ & $108 \mathrm{a}$ & $119 \mathrm{a}$ \\
\hline Late & $26.9 \mathrm{a}$ & $28.3 \mathrm{~b}$ & $23.5 \mathrm{a}$ & $14.6 \mathrm{~b}$ & $13.7 \mathrm{a}$ & $8.5 \mathrm{c}$ & $32.5 \mathrm{a}$ & $32.2 \mathrm{~b}$ & $37.9 \mathrm{a}$ & $106 a$ & $116 a$ \\
\hline \multicolumn{12}{|l|}{ Storage $(\mathrm{d})$} \\
\hline 0 & 29.6 & 31.7 & 25.4 & 18.3 & 7.1 & 9.8 & 32.7 & 35 & 36.9 & 108 & 117 \\
\hline 7 & --- & 30.1 & 23.2 & --- & 10.1 & 9.6 & --- & 32.8 & 38 & 108 & 118 \\
\hline 14 & 27.9 & 24.5 & 22.8 & 14.4 & 15.1 & 9.6 & 31.9 & 32.4 & 34.9 & 107 & 116 \\
\hline 21 & 25.5 & 28.1 & --- & 14.4 & 14 & --- & 29.8 & 30 & --- & 105 & -- \\
\hline $\mathrm{L}$ & $* *$ & $* *$ & $* * *$ & NS & NS & NS & $* *$ & $* *$ & NS & $* *$ & NS \\
\hline $\mathrm{C}$ & NS & NS & NS & NS & NS & NS & NS & NS & NS & NS & NS \\
\hline
\end{tabular}

${ }^{\mathrm{z}}$ Harvest dates: early $=4$ to $5 \mathrm{~d}$ before commercial harvest date; commercial $=$ commercial harvest date; late $=4$ to $5 \mathrm{~d}$ after commercial harvest date.

${ }^{y}$ Means in a column within harvest not followed by a common letter are significantly different $(P \leq 0.05)$.

$\mathrm{ns}^{\star},{ }^{* \star},{ }^{* \star *},{ }^{* \star * \star}$ Nonsignificant or significant at $P \leq 0.05,0.01,0.001,0.0001$, respectively; $\mathrm{L}=$ linear effect, $\mathrm{C}=\mathrm{curvilinear}$ effect. 
1981). The changes in SSC and TA of 'Lapins' cherries during storage resulted in increased SSC/TA ratio values (data not shown) which might enhance consumer acceptance.

Both fruit and pedicel color of 'Lapins' cherries were influenced by both harvest and storage (Table 2 ). Fruit color was rated as darker (lower $\mathrm{L}^{*}$ color value) due to harvest delay in only 1 year of this study. As storage time increased, fruit displayed consistently lower $\mathrm{L}^{*}$ values in all years of the study. In general the longer fruit remains on the tree the more red color develops. In 2 of the 3 years of this study, red color intensity increased (lower hue values) as harvest was delayed. The reverse was true (higher hue values) in 1 year. Higher hue values for the year in question, 2000, occurred only on the late harvest date; insufficient crop remaining may have influenced the choice of fruit that year.

Pedicel color and appearance have been used as criteria for determining cherry market value. In this study, harvest date had little or no influence on pedicel color (Table 2 ). Both $\mathrm{L}^{*}$ and hue color values remained the same over the harvest interval, except for $L^{*}$ in 2000 . Pedicel $L^{*}$ color values became darker (lower values) between early and commercial harvest, but remained the same between commercial and late harvest. $L^{*}$ values were reduced by only one unit during this time period; it is doubtful that such a small difference could be detected by the consumer, especially in light of the absence of a change in hue value for this same period. Time in storage influenced pedicel color in terms of both darkness and hue values. Reduced L* values were evident as storage time progressed regardless of the year. Reduced $L^{*}$ values coupled with reduced hue values were particularly evident after $14 \mathrm{~d}$ of storage. These lower $\mathrm{L}^{*}$ and hue values would indicate a darker, less green pedicel as storage time progressed.

In 1999, there was an interaction between harvest date and storage time for hue values, but no consistent pattern was present (Table 4). Early-harvested cherries exhibited greener pedicels with longer storage time. Pedicel color for cherries from the commercial and late harvest became less green as storage time progressed. These color differences between harvest time and storage were apparent only in the first year of the study. In the other 2 years of the study (Table 2 ), pedicel color was darker as storage progressed.

Increased pitting and bruising related to delayed harvest and storage has been reported by packers of 'Lapins' sweet cherries (T. Facteau and E.M. Kupferman, personal communications). During this 3-year study, pitting and bruising showed no relation to time of harvest (Table 3 ). Incidence

Table 3. Subjective quality ratings for 'Lapins' sweet cherries as influenced by harvest date and storage time.

\begin{tabular}{|c|c|c|c|c|c|c|c|c|c|c|}
\hline \multirow[b]{2}{*}{ Factor } & \multicolumn{3}{|c|}{ Pitting (\%) } & \multicolumn{3}{|c|}{ Bruising (\%) } & \multicolumn{2}{|c|}{$\begin{array}{c}\text { Fruit } \\
\text { appearance }^{\mathrm{x}}\end{array}$} & \multicolumn{2}{|c|}{$\begin{array}{c}\text { Pedicel } \\
\text { appearance }^{\mathrm{x}}\end{array}$} \\
\hline & 1999 & 2000 & 2001 & 1999 & 2000 & 2001 & 2000 & 2001 & 2000 & 2001 \\
\hline \multicolumn{11}{|l|}{ Harvest $^{\mathrm{z}}$} \\
\hline Early & $3.8 \mathrm{a}^{\mathrm{y}}$ & $17.5 \mathrm{ab}$ & $7.4 \mathrm{a}$ & $2.1 \mathrm{a}$ & $19.8 \mathrm{a}$ & $3.0 \mathrm{a}$ & $1.0 \mathrm{a}$ & $1.2 \mathrm{a}$ & $1.0 \mathrm{a}$ & $1.2 \mathrm{a}$ \\
\hline Commercial & $2.7 \mathrm{a}$ & $21.5 \mathrm{a}$ & $3.8 \mathrm{a}$ & $3.9 \mathrm{a}$ & $18.8 \mathrm{a}$ & $4.3 \mathrm{a}$ & $1.1 \mathrm{a}$ & $1.2 \mathrm{a}$ & $1.1 \mathrm{a}$ & $1.1 \mathrm{a}$ \\
\hline Late & $3.9 \mathrm{a}$ & $16.5 b$ & $10.4 \mathrm{a}$ & $3.8 \mathrm{a}$ & $19.4 \mathrm{a}$ & $7.6 \mathrm{a}$ & $1.1 \mathrm{a}$ & $1.0 \mathrm{a}$ & $1.1 \mathrm{a}$ & $1.0 \mathrm{~s}$ \\
\hline \multicolumn{11}{|l|}{ Storage $(\mathrm{d})$} \\
\hline 0 & 3.9 & 11.3 & 4.7 & 1.1 & 9.2 & 1.0 & 1.0 & 1.0 & 1.0 & 1.0 \\
\hline 7 & --- & 23.3 & 10.8 & --- & 18.3 & 7.5 & 1.1 & 1.1 & 1.0 & 1.0 \\
\hline 14 & 3.0 & 19.2 & 6.4 & 3.8 & 23.3 & 6.6 & 1.0 & 1.3 & 1.1 & 1.3 \\
\hline 21 & 2.9 & 20.0 & --- & 4.9 & 26.4 & --- & 1.1 & --- & 1.1 & --- \\
\hline $\mathrm{L}$ & NS & * & NS & * & $* * *$ & NS & NS & NS & * & NS \\
\hline $\mathrm{C}$ & NS & * & NS & NS & NS & NS & NS & NS & NS & NS \\
\hline
\end{tabular}

${ }^{\mathrm{z}}$ Harvest dates: early $=4$ to $5 \mathrm{~d}$ before commercial harvest date; commercial $=$ commercial harvest date; late $=4$ to $5 \mathrm{~d}$ after commercial harvest date.

y Means in a column within harvest not followed by a common letter are significantly different $(P \leq 0.05)$.

xAppearance rating: 1 = excellent, 2 = acceptable, 3 = unacceptable.

$\mathrm{ns}^{*},{ }^{* \star * * * *},{ }^{* * *}$ Nonsignificant or significant at $P \leq 0.05,0.01,0.001,0.0001$, respectively; $\mathrm{L}=$ linear effect, $\mathrm{C}=\mathrm{curvilinear}$ effect.

Table 4. Pedicel color and appearance and fruit appearance of 'Lapins' sweet cherries as influenced by the interaction of harvest and storage time in $1999 .^{\mathrm{z}}$

\begin{tabular}{|c|c|c|c|c|c|c|c|c|c|}
\hline \multirow{3}{*}{$\begin{array}{l}\text { Storage } \\
\text { (d) } \\
\end{array}$} & & & & \multicolumn{3}{|c|}{ Harvest $^{\mathrm{x}}$} & \multirow[b]{2}{*}{$\mathbf{E}$} & \multirow[b]{2}{*}{$\mathbf{C}$} & \multirow[b]{2}{*}{$\mathbf{L}$} \\
\hline & $\mathbf{E}$ & $\mathbf{C}$ & $\mathbf{L}$ & $\mathbf{E}$ & $\mathrm{C}$ & $\mathbf{L}$ & & & \\
\hline & \multicolumn{3}{|c|}{ Pedicel hue } & \multicolumn{3}{|c|}{ Pedicel appearance $^{\mathrm{y}}$} & \multicolumn{3}{|c|}{ Fruit appearance $^{y}$} \\
\hline 0 & 107 & 106 & 108 & 1.0 & 1.0 & 1.0 & 1.0 & 1.0 & 1.1 \\
\hline 7 & --- & --- & --- & --- & --- & --- & --- & --- & --- \\
\hline 14 & 106 & 95 & 115 & 1.2 & 1.4 & 1.2 & 1.2 & 1.3 & 1.2 \\
\hline 21 & 111 & 93 & 93 & 1.3 & 2.0 & 2.2 & 1.2 & 1.6 & 1.8 \\
\hline Linear & * & * & NS & * & * & ** & * & * & * \\
\hline Curvilinear & NS & NS & NS & NS & * & $* * * *$ & NS & NS & * * \\
\hline
\end{tabular}

${ }^{\mathrm{z}}$ Individual regressions within harvest dates due to the interaction of harvest date with storage time.

yAppearance rating: 1 = excellent, $2=$ acceptable, $3=$ unacceptable.

${ }^{\mathrm{x}}$ Harvest dates: $(\mathrm{E})$ early $=4$ to $5 \mathrm{~d}$ before commercial harvest date; $(\mathrm{C})$ commercial $=$ commercial harvest date; $(\mathrm{L})$ late $=4$ to $5 \mathrm{~d}$ after commercial harvest date

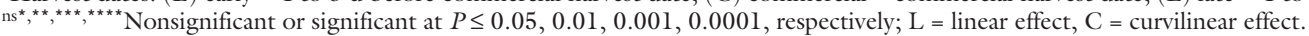


of pitting and bruising was low in 2 of the 3 years of this study; both parameters showed little relationship to the time of harvest. Longer storage time was associated with increased pitting and bruising, but again these factors were related more to the year rather than time in storage. In 2 of the 3 years, no significant increase in pitting was observed as storage time increased. During the year of highest incidence of these disorders (2000), there was a significant increase in both pitting and bruising as storage time increased.

'Lapins' fruit appearance was influenced by harvest time in only 1 (1999) of 3 years (Table 4). Differences were evident only at the late harvest and after $21 \mathrm{~d}$ of storage, but fruit appearance was rated as best on the earliest harvest date. Fruit appearance on the commercial and late harvest dates was rated significantly lower, but the values were still well within the range of acceptability (value $\leq 2.0$ ). No difference in fruit appearance was associated with harvest date in either of the 2 other years (Table 3 ). Fruit appearance was rated as lower (higher score) in 2 of 3 years when storage time equaled or exceeded $14 \mathrm{~d}$. The poorest appearance score after $21 \mathrm{~d}$ of storage (1.58) was still less than 2.0, the limit for acceptable appearance. In 2000 , no change in fruit appearance scores was evident for fruit stored for $21 \mathrm{~d}$.

Sweet cherries are marketed based in part on pedicel appearance. Visually rated pedicel quality was influenced by harvest date during only 1 of 3 years (Table 4). In 1999, pedicel appearance was rated best at the earliest harvest (1.15), but approached an unacceptable level for late-harvested fruit stored for $21 \mathrm{~d}$. The pedicel appearance value (1.48) for both commercial and late harvest in 1999 was considered acceptable ( 2.0 or less). In 2000 and 2001 (Table 3), no change in pedicel appearance rating was observed as harvest progressed. Regardless of the year, increased storage time was associated with a lower pedicel appearance rating (higher score).

\section{Conclusions}

'Lapins' sweet cherries can be harvested over an extended period of time with no quality loss. Harvesting fruit up to $5 \mathrm{~d}$ later than normal commercial harvest resulted in increases in fruit weight, SSC, and TA, along with no loss of firmness. Pedicel color did not change as harvest was delayed. The behavior of these important parameters of fruit quality suggest that delaying harvest a short time beyond the normal commercial harvest date could enhance consumer appeal and increase fruit value. Changes in visual ratings of both fruit and pedicel appearance with delayed harvest were detectable in only 1 of 3 years. Neither pitting or bruising was influenced by harvest date. The amount of pitting or bruising present was related more to the year of harvest rather than harvest date. Storage time after harvest resulted in reduced fruit and pedicel appearance, but only beyond $14 \mathrm{~d}$ of storage.

\section{Literature cited}

Crisosto, C.H., D. Garner, G.H. Crisosto, P. Wiley, and S. Southwick. 1997. Evaluation of the minimum maturity index for new cherry cultivars growing in the San Joaquin Valley. Calif. Cherry Growers Assn., Visalia.

Crisosto, C.H., G.M. Crisosto, and M.A. Ritenour. 2001. Testing the reliability of skin color as an indicator of quality for early season 'Brooks' (Prunus avium L.) cherry. Postharvest Biol. Technol. 24:147-154.
Drake, S.R., E.L. Proebsting, and S.E. Spayd. 1982. Maturity index for the color grade of canned dark sweet cherries. J. Amer. Soc. Hort. Sci. 107:180-183.

Drake, S.R. and J.K. Fellman. 1987. Indicators of maturity and storage quality of 'Rainier' sweet cherry. HortScience 22:283-285.

Facteau, T.J. and K.E Rowe. 1979. Factors associated with surface pitting of sweet cherries. J. Amer. Soc. Hort. Sci. 104:705710 .

Guyer, D.E., N.K. Sinha, T.S. Chang, and J.N. Cash. 1993. Physiochemical and sensory characteristics of selected Michigan sweet cherry (Prunus avium L.) cultivars. J. Food Qual. 16:355-370.

Hansche, P.E., W. Beres, J. Doyle, and W.C. Micke. 1988. 'Brooks' sweet cherry. HortScience 23:644.

Harman, H. and D.E. Bullis. 1929. Investigations relating to the handling of sweet cherries with special reference to chemical and physiological activities during ripening. Ore. Agr. Expt. Sta. Bul. 247.

Hunter, R.S. and R.W. Harold. 1987. The measurement of appearance. $2^{\text {nd }} \mathrm{ed}$. Wiley, New York.

Ingalsbe, D.W., G.W. Carter, and A.M. Neubert. 1965. Anthocyanin pigments as a maturity index for processing dark sweet cherries and purple plums. Agr. Food Chem. 13:580-584.

Patten, K.D. and E.L. Proebsting. 1986. Effect of different artificial shading durations and natural light intensities on fruit quality of 'Bing' sweet cherries. J. Amer. Soc. Hort. Sci. 111:360-363.

Proebsting, E.L. and H.M. Mills. 1981. Effects of season and crop load on maturity characteristics of 'Bing' cherry. J. Amer. Soc. Hort. Sci. 106:144-146.

Snedecor, G.W. and W.G. Cochran. 1980. Statistical methods. 7th ed. Iowa State Univ. Press, Ames. 